\title{
Multilingualism and Multiculturalism Impact on Shaping Oral Literacy and Communicative Competence
}

\author{
Nur Fadhila Ahmad1, Nabila Suhaimi', Khairun Nadrah Saidin', Abdul Azim \\ Mahda', Norizan Abdul Razak ${ }^{1}$ \\ ${ }^{1}$ School of Language Studies and Linguistics, Faculty Social Sciences and Humanities, UKM, Malaysia \\ Corresponding author: Norizan Abdul Razak [norjef@ukm.edu.my]
}

\begin{tabular}{llll}
\hline Received: 18.12 .2020 & • & Accepted: 24.12.2020 & •
\end{tabular}

\begin{abstract}
This study aimed to investigate the effect of multilingual and multicultural factors on individual oral literacy by conducting semi-structured interviews and correspondingly examine the features of the conversation from the interview session through a conversational analysis method. The investigation included having a better understanding of the strategies involved during the learning and acquisition process, the peers and surroundings of the participants, and the elements of multiculturalism and multilingualism. The findings showed that the participants had different strategies to achieve communicative competence. The results also showed that the learners achieved the communicative competence by recognizing the specific structure and features of the language (grammatical competence), understanding the historical background of the ethnicity belong to the language (sociolinguistic competence), practicing the languages (strategic competence), and understanding the language coherent by listening (discourse competence).
\end{abstract}

Keywords: multilingualism; multiculturalism; language; oral literacy; communicative competence

\section{Introduction}

Language learning could be a long-term process in an individual life. Learning other people's language means learning the culture at the same time. As a Malaysian, the wide diversity of ethnicity and races introduces us to the bilingual and multilingual environment along with the multicultural system. In general, the local Malaysian through the vernacular system at least has the ability to speak in Malay and English. According to Darus and Subramaniam (2009:283) "in general, local Malaysian students have been exposed to eleven years of learning English in primary and secondary schools." Through the various exposure from educational institutions such as universities, mass media, and social media, the learning process of the foreign languages and exploring their culture could be much easier and convenient. This study was carried out to study how the multicultural and multilingual factors mould an individual's oral literacy through an interview session.

Previously, several studies have been conducted on multilingualism and multiculturalism (Cots \& Nussbaum, 2008; Franceschini, 2011; Mokibelo, 2015; Björklund, 2013; Yassin, Razak, Qasem \& Saeed, 2020). These studies of multilingualism could be segregated into a few different purposes. According to Cots and Nussbaum (2008), the educational institution plays a great role beyond evaluating the specific capacities and skills by offering a variety of activities through the roles of experts. Also, the multilingualism and multicultural surrounding promote social harmony among society. The multilingual and multicultural environment tends to adopt the positive values of the 
sensitive, critical, and linguistically conscious society that is well-prepared for an open debate in a dynamic and pluralistic society (Björklund, 2013).

Mokibelo (2015) showed that the learners denied linguistic and cultural diversity of their languages and cultures in the classrooms, while there was evidence of celebrating culture and linguistic diversity in the society. According to Franceschini (2011), the relationship between an individual with the social embedding and multicompetence based on their experience, the relationship of a variety of multilingual skills based on the speaker, and the communicative competence highly related to the real attempt of interaction.

Multilingualism and multiculturalism play an important role in society. According to Cortazzi (1996), learning foreing languages helps the individual to understand the culture and behaviours of other countries, and language is the product of thought and the community's cultural and social behaviours. By understanding the correlation between multilingualism and multiculturalism, an individual would be able to have the communicative competence that leads to an individual's oral literacy.

Therefore, this study focuses on how an individual's oral literacy was mould and influenced by the multicultural and multilingual factors through a case study with the participants with a multilingual and multicultural background. The main objective of the study is to investigate the effects of multiculturalism and multilingualism on one's oral literacy. The study contributes to the answer to the respective research question:

How is an individual's oral literacy mould and influenced by the multicultural and multilingual factors?

\subsection{Multilingualism and Multiculturalism}

Multilingualism refers to the capability of a speaker or the community of speakers to converse or speak within three or more languages which is the opposite of monolingualism which the speaker only could speak in one respective language. Multilingualism covers a wide range of social, institutional, and the individual routine that includes the varieties of the language itself such as the national language, regional languages, sign languages and more (Franceschini, 2011). The language represents culture, heritage, and social status impact among the multilingual community which is closely related to the degree of amalgamation in the society and corresponding to the situation, the different languages might be a form of the barrier within the monolingual communities along with the language preference that could be a form of explanation on the value of the local languages in global perspectives (Kim et al., 2014).

Based on the sociology aspect, multiculturalism explained the manner of the society cope with the cultural diversity and enriched with the behaviour of peacefully respecting the other members of opposite cultures by encouraging and preserving the respective cultures. Multiculturalism was normally associated with the theories of "melting pot" and "salad bowl" theory. According to Bachmann (2006:730) "The melting pot is a metaphor for the development of heterogeneous societies whose ingredients are processed until they lose their discrete identities and yield a final product of uniform consistency and flavour." The melting pot theory is a form of cultural amalgamation where the mixture of pre-existence cultures produces a new form of societies or communities. Thornton (2012) suggests that the salad bowl metaphor describes the diversity of ethnic groups existing by preserving their very own identity separately and it was represented by the ingredients in the salad bowl while the "dressing" that integrated all of the ingredients was known as the law and the market. The multicultural society is featured by people from different races, 
ethnicities, and nationalities that live in the same community by sharing and celebrating the unique features of each lifestyle, language, custom, arts, and behaviour.

\subsection{Multilingualism and Multiculturalism: Communicative Competence}

The communicative competence model was introduced in 1980 by Canale and Swain. Canale and Swain suggested that the capability of speakers to communicate were highly related to the four different sub-competencies; grammatical competence (focused on the correct grammatical structure), sociolinguistic competence (the production of suitable sociolinguistic speech), discourse competence (the ability on constructing a coherent and cohesive speech), and strategic competencies (the capability to provide a solution on a miscommunication of utterances).

According to Kyppo et al. (2016: 244), the interactive environment could enhance learner's multilingual skills. Based on this scenario (interactive environment) the learners were being anticipated to practice the problem-based learning strategies in order to produce a solution that was almost similar to the real-life situation. Based on the claims made by Li (2018:543), "For students from different linguistic backgrounds, their interpersonal communication and relationships are strongly influenced by the language they speak. They learn to adapt their language use according to the specific situation, environment, and interpersonal dynamics with others". The growth of multiculturalism in our society requires each of us to have a better knowledge of the other ethnicity's language, culture, and communication skills.

\section{Materials and Methods}

\subsection{Research Design}

The current study adopted the qualitative design, which is suitable for this study to get sufficient data through semi-structured interviews. This qualitative data aims to describe the experience of multiculturalism and multilingualism and its impact on shaping oral literacy and communicative competence. The phenomenological qualitative approach is suitable for the study since the focus is on the commonality of participants' experience to describe the nature of multiculturalism and multilingualism in the context of shaping oral literacy and communicative competence (Creswell, \& Poth, 2016; Razak, Yassin, \& Maasum, 2020). Therefore, the researchers used semi-structured interviews to get an in-depth understanding of the phenomenon under investigation. One of the methods of carrying out semi-structured interviews is online interviews (Woods, 2011), and this study carried out interviews through online platforms such as Zoom.

\subsection{Sample}

There are four different participants from different multilingual and multicultural backgrounds that have contributed their respective data for this study through convenient sampling (Creswell, \& Poth, 2016). The current study used purposive sampling since the focus was on the multicultural and multilingual experience of the participants and its role in shaping oral literacy and communicative competence. The details of the participants as shown below.

\section{Participant A}

A postgraduate student from Universiti Sains Malaysia (USM) who speaks Malay with Penang dialect as her first language, English as her second language, and the ability to communicate in foreign languages such as Russian, Kazakhstan, Spanish and Korean language. 


\section{Participant B}

A lecturer at UITM Dengkil. She is an Indian Muslim and she speaks Malay, English, and Tamil with her family.

\section{Participant C}

A postgraduate student from Indonesia who is both multicultural and multilingual are chosen for this study. The selected participant is a male participant with the Malay language as his mother tongue and English, Arabic, and German as the other languages that he is exposed to.

\section{Participant D}

A postgraduate student from Lombok Indonesia who is doing her Master's degree in English Language Studies in UKM. Currently, she is in her second semester at UKM. She can speak in 4 different languages; Indonesian with a Balinese accent as her first language, German, English, and Bahasa Malaysia.

\subsection{Process and Data Analysis}

Online interview sessions were conducted by using video conferencing platforms such as Zoom for approximately around 16 to 20 minutes with each participant. The researchers have taken verbal permission from participants to use the data for research purposes only. The data were gathered separately by a different interviewer and the conversation from the interview session was later turned into a transcription, further analysed to answer the respective research question. During the analysis, the researchers have analysed the data into codes, and these codes were developed into themes after that. To ensure the reliability of the data, the analysis has been revised by the researchers (Creswell, \& Poth, 2016).

\section{Results and Discussion}

\section{1. The experience in learning foreign languages}

Each of the participants shared that their language learning process was different for each language and a different form of cultural settings. They are required to adapt to different forms of language learning skills. There are specific purposes for them to learn a specific language; communication, education, career, and personal interest. Table 1 shows a brief explanation of each of the participant's language learning experiences.

Table 1. Learning experiences

\begin{tabular}{|c|c|c|c|}
\hline \multirow{2}{*}{ Participants } & \multirow{6}{*}{$\begin{array}{l}\text { Excerpts } \\
\text { "Well, I would say that it is a life long experience because I've } \\
\text { learned English when I was...umm...throughout my life. And } \\
\text { then I learned...I self-taught myself Korean when I was in a } \\
\text { high school. And then...(laughing) there is...sorry for the } \\
\text { background noise...but...and then I learned Spanish and } \\
\text { Russian when I was in degree." }\end{array}$} & \multicolumn{2}{|c|}{ Learning Experiences } \\
\hline & & a) & Self-taught \\
\hline & & b) & \\
\hline & & & Prog \\
\hline & & c) & Joining a class \\
\hline & & d) & Family \\
\hline & $\begin{array}{l}\text { "when I was taking the course, I have like my classmate and } \\
\text { what not so those are my chances to practice but }\end{array}$ & & $\begin{array}{l}\text { cultural } \\
\text { background }\end{array}$ \\
\hline & $\begin{array}{l}\text { now...umm...I will have to take like self-taught myself to be } \\
\text { competent in the language. Yup." }\end{array}$ & e) & $\begin{array}{l}\text { Naturally } \\
\text { peers }\end{array}$ \\
\hline & $\begin{array}{l}\text { we learned what we need to learn because Russian we mainly } \\
\text { used outside our university. So, we need Russian to survive }\end{array}$ & f) & $\begin{array}{l}\text { Working } \\
\text { environment }\end{array}$ \\
\hline & $\begin{array}{l}\text { and...ummm... we used it a lot but we used it for survival } \\
\text { reason." }\end{array}$ & त) & Career purpose \\
\hline
\end{tabular}




\begin{tabular}{|c|c|c|c|}
\hline \multirow[t]{3}{*}{$\mathrm{B}$} & \multirow{3}{*}{$\begin{array}{l}\text { "...my entire family did practice mixture of languages when we } \\
\text { communicate. And personally, I don't face any problems as all } \\
\text { of us do understand, accept and received the information } \\
\text { successfully without any misunderstandings" } \\
\text { "As for me, when I communicate with my peers, honestly I do } \\
\text { learn new vocabulary or words" }\end{array}$} & h) & $\begin{array}{l}\text { Primary and } \\
\text { secondary } \\
\text { education }\end{array}$ \\
\hline & & i) & To study abroad \\
\hline & & j) & $\begin{array}{l}\text { For survival and } \\
\text { cultural }\end{array}$ \\
\hline \multirow[t]{2}{*}{$\mathrm{C}$} & $\begin{array}{l}\text { "... all of those skills is being polished during my diploma and } \\
\text { also my undergraduate. Then when it comes to work } \\
\text { environment... because it almost like every day... because in } \\
\text { my, in our office basically English is a core language. So, when } \\
\text { you start to speak every day, so basically it becomes your } \\
\text { nature." }\end{array}$ & & adaptation \\
\hline & $\begin{array}{l}\text { "Yeah, I did learn... I did learn... but the duration of, for } \\
\text { example English, all of us... we learn from primary school even } \\
\text { I think until now. And... but for German, I think it just take } \\
\text { about one semester, and I think based on that you know the } \\
\text { basic but practically might not... still almost near to none. Near } \\
\text { to zero." }\end{array}$ & & \\
\hline \multirow[t]{3}{*}{$\mathrm{D}$} & $\begin{array}{l}\text { "Ok (laughs), that's an interesting question, thank you. Em } \\
\text { well em the main motivation why I took English a as my } \\
\text { degree, my bachelor degree because I have a dream to travel } \\
\text { around the world" }\end{array}$ & & \\
\hline & $\begin{array}{l}\text { "And if you have an ability in international language, at } \\
\text { international language such as English, you will can able to } \\
\text { communicate to other people from other countries. That's' } \\
\text { why, yeah, I think that's the reason why I took English." }\end{array}$ & & \\
\hline & “...we just got a scholarship for taking a German course." & & \\
\hline
\end{tabular}

Participant A shared that; her learning process was different for each different language. She learned Korean since her high school days by self-taught, learning Kazakhstan and Russian languages simultaneously when she was under an exchange student (mobility) programme and joining a Spanish class during her degree day.

During her high school days, she was a Korean Pop (K-Pop) culture admirer. At that moment, the Korean famous culture was dominating the Asia mass media and both terms ("Hallyu" and "Hanryu") were known as the "Korean wave" (Shim, 2006). The "Korean wave" seems to motivate her to understand the song that she listened to.

However, it was a totally different story and surrounding where she starts to learn Russian and Kazakhstan in order to survive throughout her mobility programme. According to Berg (2016, p. 12), the exchange student programme provides a better intercultural competence development and enhances the foreign language acquisition process. In Kazakhstan, she needs to be competent enough to speak in Russian within the semester in order to make her daily life routine run smoothly and also to answer the examination which is in the language. It was a completely different learning journey in comparison with her Korean language learning journey which is less stressful.

Based on participant B experience, she could speak in three different languages by considering her multicultural family background and peers are the main factor in the development of multilingualism and multiculturalism skills. Language learning at home can be done with parental support as the children will be able to acquire all languages that they heard at an early age. A person who came from a supportive home background also will have a higher oral literacy level. Blackledge (2000) explained that the schools, the home language, and 'culture' are given token value but are marginalised as factors that can interfere with the achievement of students' social and cognitive potential. 
According to participant $\mathrm{C}$, he has grown up in Malaysia within a Malay home culture and Chinese working environment. Later, due to career development purposes, he has migrated to Doha, Qatar. The new environment involves Middle Eastern culture with a mixture of other internationals. The situation was correspondingly parallel to a statement by Baynham \& Prinsloo (2009) who believed that the supportive peers and surrounding is important in order to enhance the individual oral literacy as it should be conceptualised as a social practice. It can be said that practical language use in reallife interaction greatly contributes to the development of oral literacy compared to formal education.

Participant D shares a bit of similarity with Participant A experience. Both of the participants have gone through the exchange student programme due to their passion and interest in learning various kinds of language. She learned German as a preparatory language before going for a mobility programme in German and Malay language when she is currently pursuing her Master's degree in English Language Studies in UKM. Her determination to study abroad is one of the main factors that help her in having multilingual and multicultural skills as well as awareness. According to Taguchi and Collentine (2018, p. 557), the concept of studying abroad has been the main efforts of the tertiary level education on introducing internationalization concepts and being encouraged to learn a foreign language. As an outcome, the trend of studying abroad enhanced the development of intercultural communicative competence among the students.

\section{2. Strategies to assist the development of oral literacy}

\section{a. Sociolinguistic competence}

According to the Communicative Competence model by Canale and Swain (1980), the multilingual learning journey consisted of sociolinguistic competence, grammatical competence, strategic and discourse competence as shown in Table 2 below.

Table 2. Communicative Competence model by Canale and Swain (1980)

Communicative Competence model Sociolinguistic The production of suitable sociolinguistic by Canale and Swain (1980)

\begin{tabular}{ll}
$\begin{array}{l}\text { competence. } \\
\text { Grammatical } \\
\text { competence. }\end{array}$ & $\begin{array}{l}\text { Focused on the correct grammatical } \\
\text { structure. }\end{array}$ \\
$\begin{array}{l}\text { Strategic } \\
\text { competence. }\end{array}$ & $\begin{array}{l}\text { The capability to provide a solution to the } \\
\text { miscommunication of utterances. }\end{array}$ \\
\hline $\begin{array}{l}\text { Discourse } \\
\text { competence }\end{array}$ & $\begin{array}{l}\text { The ability to construct a coherent and } \\
\text { cohesive speech. }\end{array}$
\end{tabular}

The participants A and D have sociolinguistic competence as she learns the culture and the historical background of the language. For example, she learns that in Kazakhstan, the country was a part of the USSR (the Union of Soviet Socialist Republics). Understanding the diglossia features and status of each language by focusing on the low variety (Kazakhstan language) and high variety (Russian Language) among the Kazakhstan society by observing the language demand in the respective country. By referring to Participant $\mathrm{D}$, the participant has had in using the languages in different cultural settings by imitating their accents, stress, and intonations. For instance, the accents, stress, and intonations that the participant uses vary depending on whom she communicates with a particular language.

The participant also mentioned how she adapted Manglish as she studies in Malaysia. She could imitate the accents used by Malaysians, and follow how Malaysians would speak in Bahasa Melayu and English as well. Plus, she can use ' lah' correctly to add emphasis just like how Malaysians would do it. Here, we can see how imitations and adaptations in using the languages help the participant to 
adapt to how the people use the language and enable her to 'blend in' among the people who speak the languages.

For participant B the communication at home is very crucial in order to let the kids learn a language at an early age. Parents' support in language learning is very important. Language learning is not effective if families do not take part in it. Schools accept their role in transmitting literacy and in making special arrangements for children with difficulties. However, they will not be successful unless there is a willingness to learn on the part of children and unless families accept their responsibility to provide an environment that is conducive to learning. (DEET, 1990: 15). Language learning at home can be done with parental support because children will absorb all languages that they heard at an early age.

Lastly, the participant $\mathrm{C}$ shares the experience he had to face when it comes to communicating within a multicultural environment where even though both communicators speak the same language such as English, the different ways of pronouncing thanks to different cultural backgrounds makes it a bit challenging to understand each other. Due to this reason, it is very important in intercultural communication to clarify the information that you have received in order to avoid misconceptions. Such practices have helped him to communicate with people from various cultures and use various languages. Thus, ensuring mutual understanding during the communication process and reducing communication breakdowns as he communicates. Table 3 below shows the comments of the participants concerning sociolinguistics competence.

Table 3. Sociolinguistic competence

\section{Participants Excerpts}

A

"Before I start sharing my experience, I would like to give

a background knowledge of the history of Kazakh...Kazakhstan. So, it is once under the USSR colonization..."

“...in Kazakhstan they used both Kazakh and also Russian as a business lang... a government language there. So, that give the Russian language a bit of higher status in their country."

"...because Russian is widely accepted in the country. So, when I learned Russian it is easy of communication, it's the ease of communication for me..."

B

"...parental support and home background do influence one's oral literacy as all of us tend to learn and grow from our home with the family members..."

"Well, we need to use other language than our mother tongue if we want to speak with someone who does not understand our mother tongue very well."

"...multilingual society do help us to be better in oral literacy which is in English because sometimes we do not have choice unless to speak in English."

C

\section{Sociolinguistics competence}

a) Background knowledge and the history of the respective country

b) The diglossia features (high and low variety)

c) Multicultural and multilingual awareness among family background.

d) Cultural background of the respective country "...almost 10 years of working experience... uh, communicating with people... talking with people not only Malaysian but also foreigner.

"...I also exhibit... participate with the international exhibition."

"...and what is my accent is what you can hear as I am speaking right now. I am not sure what is the accent really, but I think this is a 'signature' of Malaysian, Malay English..." 
$\mathrm{D}$

"When I was in Germany the way I speak would be different. I mean like where I put the stress, the intonation, it would be different."

"I mean like if you listen to me right now, the way I speak is just like Malaysians. Malaysians lah...I don't know why they always put "lah" in the end"

\section{b. Grammatical competence}

The grammatical competence was achieved through the advantage of being observant that gave her a better understanding of how the sentence structure in the respective language functions. Table 4 shows the comments of the participants concerning grammatical competence.

Table 4. Grammatical competence

\begin{tabular}{lll}
\hline Participants & Excerpts & Grammatical competence \\
\hline A & $\begin{array}{l}\text { "Russian is a little bit different. It has its own writing system } \\
\text { it has gender in their language. So, these are one of the issues } \\
\text { that I have when I was learning that language." }\end{array}$ & $\begin{array}{l}\text { Fomponents, structure, and } \\
\text { basic characteristics }\end{array}$ \\
\hline D & $\begin{array}{l}\text { "By the way it was very confusing at that time. Because there } \\
\text { are some similarities between German and English. But the } \\
\text { difference is on the grammar itself. Because German has a lot } \\
\text { of grammar. It's more than 16 compared to what we have in } \\
\text { English." }\end{array}$
\end{tabular}

According to Mazari and Derraz (2015:354), "The study of foreign languages widens the experience in the language field by allowing comparisons between several languages". The deep analysis and understanding of the characteristics and the use of the language structure such as the gender in the language (Kazakhstan), the numerous numbers of verbs in Spanish, the 16 different grammars in German in comparison with English and nouns make the learning much more fruitful. For instance, some languages were taught by focusing on grammar first, and it might be hard for people to acquire grammatical knowledge at the early stage of the language learning process. It would make them more aware of their grammar as they try to use the language. However, the anxiety of making mistakes and errors will cause them to be afraid to communicate the language.

The study made by Bentsen (2017) highlights that despite the mistake rate made by learners, it does not indicate the mistakes made in oral communication to be a barrier to the learners' use of language. Moreover, Bentsen (2017) also expresses that it is not necessarily efficient to focus on the largest mistake categories in oral communication. Besides, it might be useful to focus on determiners, verb tenses, and prepositions as such grammatical elements will hinder communication by creating misunderstanding. Ellis (2009) also states that the learners' utterances do not need to be accurate or "correct" to produce a meaningful communication. Fluency and accuracy complement productive language use. Therefore, teachers should help the learners to develop the skills needed for fluency to create effective communication.

\section{c. Discourse competence}

The findings of this section are categorised into four main themes, namely watching movies with subtitles, analysing the meaning of the lyrics, acquiring new vocabulary through a working environment, and entering a language course. Table 5 below shows excerpts from the interviews concerning discourse competence. 
Table 5. Discourse competence

\begin{tabular}{|c|c|c|c|}
\hline Participants & Excerpts & \multicolumn{2}{|c|}{ Discourse competence } \\
\hline \multirow[t]{2}{*}{ A } & \multirow{2}{*}{$\begin{array}{l}\text { "everytime when I watched the movie and they have } \\
\text { phrases and, phrases that interest me when I read the } \\
\text { subtitles those are that keep in my brain. It gives impact. So, } \\
\text { people said that when you learn a language and that } \\
\text { language give impact to you some and mean their brain so } \\
\text { like...hmm" }\end{array}$} & \multirow{3}{*}{$\begin{array}{l}\text { a) } \\
\text { b) } \\
\text { c) }\end{array}$} & $\begin{array}{l}\text { Watching movies } \\
\text { with subtitles }\end{array}$ \\
\hline & & & \multirow{2}{*}{ 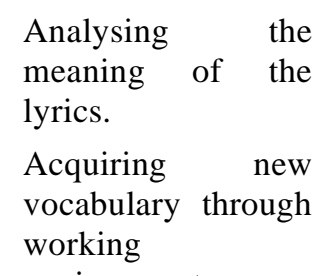 } \\
\hline B & $\begin{array}{l}\text { "Basically, by watching movies and listening to songs } \\
\text { (going thru the lyrics as well)." }\end{array}$ & & \\
\hline $\mathrm{C}$ & $\begin{array}{l}\text { "I polished a lot, I improved a lot on my vocabulary... } \\
\text { because compared to after I finish... after I graduate versus } \\
\text { after } 10 \text { years, almost } 10 \text { years of working experience... uh, } \\
\text { communicating with people... talking with people not only } \\
\text { Malaysian but also foreigners." }\end{array}$ & \multirow[t]{2}{*}{ d) } & \multirow[t]{2}{*}{$\begin{array}{l}\text { Entering a language } \\
\text { course. }\end{array}$} \\
\hline $\mathrm{D}$ & $\begin{array}{l}\text { "fulfil the language requirements first and then you can go } \\
\text { to another country." }\end{array}$ & & \\
\hline
\end{tabular}

To practice discourse competence as a form of exercise on producing a coherent and cohesive speech, the learners make their very own effort on gathering learning resources such as movies and songs. The translation provided by the subtitles could be effective in a pedagogical field that involves writing, oral skills, grammar, vocabulary, and cultural features (Ayand \& Shafiee, 2016).

The participants enhance their oral skills by matching the subtitles with the sounds and phonological features of the respective words and phrases to get the meaning and help her string the sentences in her speech. The desire to learn by going through the lyrics of English songs to learn new vocabulary is crucial in language learning because it is an accepted fact that learners come with a host of strategies that help them to function as active and effective learners (Cohen, 1998).

Leki (2007) stated that language learning is related to various social factors as learners interact in human activities. It explains very well how the language involuntary learning and acquisition process begins and continues in a formal or informal situation such as communicating with a variety of language speakers.

According to Kondrateva et al., (2016, p. 1054) "The exercises for listening training should be considered working closely listening to speaking and listening to reading as two types of receptive activity". Listening skills could help to enhance one's oral literacy skills. Therefore, a good command of a language requires both listening and speaking skills.

\section{d. Strategic competence}

The findings of strategic competence are categorized into three main themes, which are: to use correct pronunciation, to speak clearly, and using a non-verbal gesture as a clue. Table 6 below shows excerpts from the interviews regarding strategic competence.

Table 6. Strategic competence

\begin{tabular}{|c|c|c|}
\hline Participants & Excerpts & Strategic competence \\
\hline A & $\begin{array}{l}\text { "...this is just that although we don't probably don't know how } \\
\text { to spell it but at least you're saying it properly and they } \\
\text { understand what are we saying." }\end{array}$ & $\begin{array}{l}\text { a) To use a correct } \\
\text { pronunciation } \\
\text { b) To speak clearly }\end{array}$ \\
\hline B & $\begin{array}{l}\text { "... my entire family did practice mixture of languages when } \\
\text { we communicate." } \\
\text { "... I will try to speak loudly and clearly so that I want the } \\
\text { receivers to understand the information or the message being } \\
\text { send." }\end{array}$ & $\begin{array}{l}\text { c) Using a non-verbal } \\
\text { gesture as a clue. }\end{array}$ \\
\hline
\end{tabular}




\begin{tabular}{ll}
\hline C & "So based on these group of people, sometime I noticed when \\
& I speak... I speak slowly and not quite so... but I speak \\
"clear'...... so means sentence by sentence."
\end{tabular}

The interaction within the members of society the learners could enhance their speaking skills and at the same time build their self-confidence level to utilize the language. This validates a study by Kyppo (2016) which explained the importance of interactive environments on building the learner's multilingual skills. Based on this scenario (interactive environment) the learners were being anticipated to practice the problem-based learning strategies in order to produce a solution that was almost similar to the real-life situation (Cortazzi, 1996). The practice of real-life conversation by practicing to be clear in terms of pronunciation could avoid as much as miscommunication among the speakers.

\section{Conclusion}

In conclusion, the learners' experience was highly associated with the surroundings of the learners. To be proficient speakers, one needs to be aware of the communicative competencies' elements. The awareness of the importance of multilingualism and multiculturalism could be a fundamental basis for understanding the variety of cultures and embedding the respect values among the universal society.

In this society, interlanguage will interfere with the first language because learners tend to choose a language that both parties in a conversation understand and can speak very well. According to the sociocultural theorists, Lave and Wenger (1991: p.91) suggested that learning could be characterised as an interaction among three factors, which are: "structuring resources that shape the process and content of learning possibilities, the sociopolitical organization of practice of its content and the artifacts engaged in the practice and finally the identity and motivation ... generated as newcomers move toward full participation in communities of practice". Based on this statement, learners will learn in a situation where it helps them to focus on learning such as in a multilingual society.

In terms of multicultural influence on an individual's oral literacy, it can be assumed that it relies heavily on the duration in which the individual is being exposed to. For future research, the researcher could contribute the importance of the higher educational institution as the diasporic agent to help the students discover more on multilingual skills by student's exchange programme, exchange students programme or even the internship programme. In order to acknowledge various groups, communities and organisations build trust, respect and are also benefited from the different backgrounds, skill, experience, and new ways of thinking these platforms could be the main factors that act as a form of catalyst in enhancing the foreign language capacity and competence among the university students by focusing on the relatable theory models as a framework.

\section{Implications and Directions for Future Research}

Based on the experiences of each of the participants, the undying passion and interest to learn a language as the basis of living in a multicultural country (Malaysia) make them realizes that learning other ethnicity languages and cultures are a part of our society for at least as a Malay we knew and learned certain basic words from the other ethnicity such as thank you in Chinese (Xie Xie), Tamil (Nanri) and more.

In terms of multicultural influence on an individual's oral literacy, it can be assumed that it relies heavily on the duration in which the individual is being exposed to as well as the surrounding. The 
multilingual society as well provides and does influence one's oral literacy according to the sample of the study. The awareness of learning and understanding the other culture also was driven by the future career to be more competent in different languages.

Jabeen (2019) states that the most effective way to create a multicultural environment in language teaching among the learners is by providing equal opportunities for them to take part in the teaching process. Such respect for cultural background and opportunities will help them to understand more about the various cultures themselves. Therefore, the educator should play a prior role by providing a better education based on the knowledge in relation to cultures and language in order to help the learners to be aware of a new cultural context and bridging the gap between cultures in language learning.

The digital platforms are an open source for the learners to have abundant resources while the community and the society is the catalyst that helps the speakers to achieve communicative competence through the daily communication process. The ability to speak various types of languages could be an open door for someone to learn various types of cultures.

This study has limitations since the findings were driven from interviews with four participants. Therefore, other studies might use a mixed-method design in order to collect data from a large number of participants to generalize the findings. Another future research direction is focusing on the role of media on multilingualism and multiculturalism in terms of its impact on oral literacy.

\section{References}

Ayand, F. K. \& Shafiee, S. (2016). Effects of English and Persian subtitles on oral fluency and accuracy of intermediate Iranian EFL learners. International Journal of Applied Linguistics and English Literature 5(3): 133-144.

Bachmann, A. S. (2006). Melting pot or tossed salad? Implications for designing effective multicultural workgroups. Management International Review 46(6): 721-748.

Baynham, M. \& Prinsloo, M. (2009). Introduction: The future of literacy studies. In Baynham, M. $\&$ Prinsloo, M. (Eds.), The future of literacy studies. pp. 1-20. Great Britain: Palgrave Macmillan.

Bentsen, L. G. (2017). To teach, or not to teach grammar?-Teachers' approaches to grammar teaching in lower secondary school (Master's thesis).

Berg, V. (2016). Does International Student Exchange Contribute to Educating Teachers We Need in a Multicultural Society?. FLEKS-Scandinavian Journal of Intercultural Theory and Practice, $3(2)$.

Björklund, M. (2013). Multilingualism and multiculturalism in the Swedish-medium primary school classroom in Finland - Some teacher views. International Electronic Journal of Elementary Education 6(1): 117-135.

Blackledge, A. (2000). Monolingual ideologies in multilingual states: Language, hegemony and social justice in Western liberal democracies. Sociolinguistic Studies 1(2): 25-45.

Canale, M. \& Swain, M. (1980). Theoretical bases of communicative approaches to second language teaching and testing. Applied Linguistics 1(1): 1-47.

Cohen, A.D. (1998). Strategies in Learning and Using a Second Language. Essex, U.K.: Longman. 
Cortazzi, M., \& Jin, L. (1996). Cultures of learning: Language classrooms in China. Society and the language classroom, 169(206), 42.

Cots, J. M. \& Nussbaum, L. (2008). Communicative competence and institutional affiliation: Interactional processes of identity construction by immigrant students in catalonia. International Journal of Multilingualism 5(1): 17-40.

Creswell, J. W., \& Poth, C. N. (2016). Qualitative inquiry and research design: Choosing among five approaches. Sage publications.

Darus, S. \& Subramaniam, K. (2009). Error analysis of the written English essays of secondary school students in Malaysia: A case study. European Journal of Social Sciences 8(3): 483-495.

Ellis, R. (2009). The differential effects of three types of task planning on the fluency, complexity, and accuracy in L2 oral production. Applied linguistics, 30(4), 474-509.

Franceschini, R. (2011). Multilingualism and multicompetence: A conceptual view. Modern Language Journal 95(3): 344-355.

Jabeen, R. (2019). Multicultural Diverse Classroom Addressing the Instructional Challenges and Reflections, from a Teacher's Perspective. Arab World English Journal (AWEJ) Special Issue: The Dynamics of EFL in Saudi Arabia.

Kim, S., Weber, I., Wei, L., \& Oh, A. (2014, September). Sociolinguistic analysis of Twitter in multilingual societies. In Proceedings of the 25th ACM conference on Hypertext and social media (pp. 243-248).

Kondrateva, I. G., Safina, M. S. \& Valeev, A. A. (2016). Listening as a method of learning a foreign language at the non-language faculty of the university. International Journal of Environmental and Science Education 11(6): 1049-1058.

Kyppö, A., \& Natri, T. (2016). Promoting multilingual communicative competence through multimodal academic learning situations. CALL communities and culture-short papers from EUROCALL 2016 Edited by Salomi Papadima-Sophocleous, Linda Bradley, and Sylvie Thouësny, 243.

Lave, J., \& Wenger, E. (1991). Learning in doing: Social, cognitive, and computational perspectives.Situated learning: Legitimate peripheral participation. Cambridge University Press.

Leki, I. (2007). Undergraduates in a second language: Challenges and complexities in academic literacy development. New York: Lawrence Erlbaum Associates.

Li, H. (2018). Multicultural Communication Competence and Education in Ethnic Minority Areas of Yunnan. Theory and Practice in Language Studies 8(5): 541. doi:10.17507/tpls.0805.13

Mazari, A., \& Derraz, N. (2015). CULTURAL STUDIES ISSN 2356-5926. International Journal of Humanities and Cultural Studies, 2(1), 382.

Mokibelo, E. (2015). The outcomes of learning a foreign language: cases of rural primary schools in Botswana. US-China Education Review, 5(9), 573-590.

Razak, N. A., Yassin, A. A., \& Maasum, T. N. R. T. M. (2020). Formalizing Informal CALL in Learning English Language Skills. In Enhancements and Limitations to ICT-Based Informal Language Learning: Emerging Research and Opportunities (pp. 161-182). IGI Global. 
Ahmad et al. (2020): Multilingualism and Multiculturalism Impact on Shaping Oral Literacy and Communicative Competence

Shim, D. (2006). Hybridity and the rise of Korean popular culture in Asia. Media, Culture and Society 28(1).

Taguchi, N. \& Collentine, J. (2018). Language learning in a study-abroad context: Research agenda. Language Teaching 51(4): 553-566.

Thornton, B. (2012). Melting Pots and Salad Bowls, Hoover Institution (4): 1-2. Retrieved from http://www.hoover.org/research/melting-pots-and-salad-bowls

Wang, Z. \& Zheng, Y. (2019). Chinese university students' multilingual learning motivation under contextual influences: a multi-case study of Japanese majors. International Journal of Multilingualism (June).

Woods, M. (2011). Interviewing for research and analysing qualitative data: An overview. Massey University, 67-80.

Yassin, A. A., Abdul Razak, N., Qasem, Y. A., \& Saeed Mohammed, M. A. (2020). Intercultural Learning Challenges Affecting International Students' Sustainable Learning in Malaysian Higher Education Institutions. Sustainability, 12(18), 7490. 